\title{
Adsorption and affinity of Escherichia coli to different aggregate sizes of a silty clay soil
}

\author{
Filipe BEHRENDS KRAEMER ${ }^{1}$, Celio Ignácio CHAGAS ${ }^{2}$, Diego Julián COSENTINO ${ }^{3}$, \\ and Lucas Alejandro GARIBALDI ${ }^{4}$
}

\begin{abstract}
The sediments produced by water erosion are the main source of pollution of agricultural origin of surface water bodies. These sediments may be associated to bacteria, compromising the quality of nearby water bodies. Therefore, to understand this biological contamination, it is necessary to find out the adsorption capacity and bacterial affinity to aggregate sizes that may result in a differential sedimentation. To this end, in the present work, the distribution, adsorption capacity and affinity to different aggregate sizes of two strains of Escherichia coli in two liquid media of contrasting ionic strength were evaluated in a silty clay soil. The $<2 \mu \mathrm{m}$ fraction showed a higher proportion of bacteria than the other aggregate sizes (48\%), whereas among the fractions $>2 \mu \mathrm{m}$, the 20-50 $\mu \mathrm{m}$ fraction was the one that showed the highest bacterial adsorption in both liquid media $(37.9 \%)$. On the other hand, the highest values of bacterial affinity were found in the 20 to $50 \mu \mathrm{m}$ fraction (coarse silt) in the low ionic strength media and $20-50$ and $>50 \mu \mathrm{m}$ in the high ionic strength media. However, the bacterial strains used revealed only some trends in the modification of these variables. This work contributes to the development and implementation of strategies to mitigate pollution, such as control of sediment generation and its subsequent capture in filter strips.
\end{abstract}

Key Words: Biological contamination, Surface transport, Water quality

\section{Introduction}

The sediments produced by water erosion and transported by runoff are the main source of pollution of agricultural origin of surface water bodies. Depending on the degree of chemical and biological contamination, the quality of these water bodies can be significantly reduced (Chagas, 2007). The concentration of microorganisms in the sediments is governed both by their degree of association and survival in solid particles (Guan et al., 2003; Chagas, 2007; Ling et al., 2002) and by the intrinsic characteristics of the sediment itself (Burton et al., 1987). The quantification of these factors is key to the modeling of the process of biological contamination. When heavy rains occur on soils with high concentrations of microorganisms in the upper horizon, the runoff that takes place from higher lands to lower lands will carry large amounts of microorganisms to watercourses (Oliver et al., 2005; Signor et al., 2005). The particles of clay, silt and sand also reach the watercourses, which, as a result, decrease their quality (Chagas, 2007). However, it is unclear whether microorganisms are mobilized independently of soil particles, or whether the soil particles act as their means of transport (Kay et al., 2007; Jamieson et al., 2004; Tyrrel and Quinton, 2003). If microorganisms such as bacteria are associated to soil particles, they may undergo sedimentation processes that depend on the properties of the solid to which they are associated, such as density and size of the particle (Schillinger and Gannon, 1985). Thus, to understand the dynamics of bacterial transport, it is important to know not only the amount of sediment produced, but also its particle size distribution (Sutherland, 1983). The importance of the association between bacteria and soil particles is also given by the impact on the survival of these microorganisms in the liquid medium. Some studies point out that certain pathogens can survive longer in surface waters when they are associated to sediments that are either

${ }^{1}$ Agr. Eng M. Sc., Department of Soil Use and Management, School of Agronomy Buenos Aires University. Buenos Aires, Argentina. E-mail: filipebk@agro.uba.ar.

2 Dr., Department of Soil Use and Management, School of Agronomy Buenos Aires University. Buenos Aires, Argentina. E-mail: chagas@agro.uba.ar.

3 Dr., Department of Edaphology, School of Agronomy Buenos Aires University. Buenos Aires, Argentina. E-mail: cosenti@agro.uba.ar.

${ }^{4}$ Dr., National University of Río Negro, Andina branch, San Carlos de Bariloche, Río Negro, Argentina and National Scientific and Technical Research Council (CONICET). E-mail: garibaldi@unrn.edu.ar.

Note: The original manuscript of this paper was received in May 2012. The revised version was received in May 2013. Discussion open until Dec. 2014. 
suspended or deposited at the bottom of watercourses (Sherer et al., 1992; Edwards et al., 1997). Although several works have found significant quantities of sediment-associated pathogens, the distribution of microorganisms according to the sizes of particles is still uncertain. Schillinger and Gannon (1985) reported that about 15-20\% of the fecal coliform bacteria present in storm water were adsorbed to soil aggregates, mostly with diameters $>30 \mu \mathrm{m}$. In contrast, Muirhead et al. (2005) emphasized that, in field tests, the bacteria were predominantly associated to small particles; however, they also stated that it is possible that the bacteria associated with large particles had been quickly removed, leaving the free bacteria or those associated with small particles in the water current. Oliver et al. (2007) reported the existence of a preferential association of bacteria from fecal matter (e.g. E. coli) to different sizes of soil aggregates. They found that, in silty clay soils, $35 \%$ of the $E$. coli cells were associated with aggregates $>2 \mu \mathrm{m}$ and that most of this $35 \%$ were linked to fractions between 4 and $15 \mu \mathrm{m}$. Finding out the bacterial adsorption capacity and affinity is of great value for the development and implementation of strategies to mitigate pollution, such as the control of the generation of sediments and their subsequent capture in filter strips. The microbial adsorption and affinity to soil particles is influenced by a large number of factors, including the electrostatic attraction (Marshall, 1975), the cell-surface hydrophobicity (Strenstrom, 1989), the type of clay present (Stotzky et al., 1985), and the ionic environment of the water-soil mixture and its interface (Gannon et al., 1991). The latter, in particular, can be modified during a rainfall event. The heterogeneous characteristics of the liquid medium from the rainfall to the runoff deposition and the different status of the bacteria involved in this process allow establishing diverse environments where bacterial association occurs.

Fontes et al. (1991) studied the movement of bacteria in soil columns with contrasting textures and ionic media and found that bacterial retention was almost total in the soil with fine texture and high ionic strength and of only $10 \%$ in the soil with coarse texture and low ionic strength. However, few studies have assessed these factors by discriminating by soil particle or aggregate size. The study of the bacteria-sediment association in natural situations will allow a better understanding of the dynamics of bacterial transport. The use of indicators of biological contamination such as the presence of $E$. coli has become widespread both in pollution monitoring activities and in research. However, the bacterial strain used can also vary the association between the microorganisms and the soil. The features of the biological cell present (e.g. size, shape, presence of polysaccharides, etc) may change the balance of electrostatic forces and the force of collision, among other mechanisms, thus varying the resulting adsorption and affinity. In this aspect, there is very little quantitative information regarding the use of different strains associated with the soil and even less information of this association discriminated by aggregate size.

Therefore, the aim of this study was to quantify bacterial adsorption and affinity in various aggregate sizes of a silty soil in a medium with low ionic strength (distilled water) and another one with high ionic strength (small pound water), with two bacterial strains (a laboratory strain and wild strain).

\section{Materials and methods}

\subsection{Description of the soil and water under study}

Soil from the middle third of the watershed of the Tala stream in the department of San Pedro, Buenos Aires,

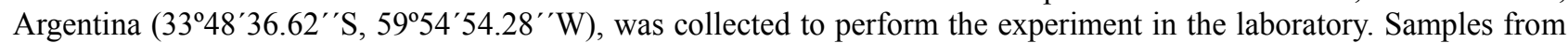
$0-5 \mathrm{~cm}$ depth were collected from a high and tilted environment, with a slope between $1 \%$ and $2 \%$. The soils in these areas consist of high erosion phases and typic vertic Argiudolls (INTA, 1973). The land is used mainly for annual extensive crops and, to a lesser extent, for cattle wintering.

The soil presented the features characteristic of an eroded and later sedimented phase, superficially enriched with organic carbon and clay. The mineralogy consisted of 2:1 clays, mainly illites, with a small proportion of kaolinite and interstratified illite/smectite (Kraemer et al., 2011a). Samples were air-dried and sieved through $2 \mathrm{~mm}$ for further analysis. The following parameters were determined: $\mathrm{pH}$ (1:2.5 solid: water), organic carbon (OC) (Walkley and Black, 1934), electrical conductivity in saturated paste (EC), exchangeable cations (ammonium acetate 1N, pH 7), cation exchange capacity (CEC) (Klute, 1986), and specific surface area (SSA) (Lombardi et al., 2001). Particle size distribution was analyzed by the pipette method of Robinson (Soil Conservation Service, 1972) (Table 1a).

For the assays with bacteria in the laboratory, we used two different liquid media. A low ionic strength water (LIS) -distilled water- and a high ionic strength water (HIS) collected in a small pound near the area were the soil of this study was sampled. Both liquid media were chosen in order to simulate the ion concentrations in rainfall and runoff respectively. LIS and HIS water were analyzed for $\mathrm{pH}$, cations and anions (in solution) and electrical conductivity with the methodologies presented above (Table $1 \mathrm{~b}$ ). The determination of the ionic strength of both liquids media took into account the ions present in the soil solution, reaching values of 0.0021 and 0.024 for LIS and HIS respectively.

Prior to the start of the experiments, the soil and water were sterilized in the Centro Atómico Ezeiza (CNEA) by applying the equivalent of $25 \mathrm{kGy} \mathrm{h}^{-1}$ of ionizing radiation, a level that does not cause changes in the structure of the soil particles. This allowed avoiding the use of chemical reactive that could have left harmful remains for the microorganisms that were later inoculated (Chagas, 2007). The effectiveness of this technique has been confirmed in earlier works (Kraemer et al., 2008; Kraemer et al., 2011b). 
Table 1 a) Physical and chemical properties of the soil tested; OC: organic carbon; CEC: cation exchange capacity; SSA: specific surface area; and EC: electrical conductivity

\begin{tabular}{|c|c|c|c|c|c|c|c|c|c|c|c|}
\hline \multirow[t]{2}{*}{$\mathrm{pH}$} & $\mathrm{OC}$ & CEC & SSA & EC & $\mathrm{Na}^{+}$ & $\mathrm{K}^{+}$ & $\mathrm{Ca}^{2+}$ & \multirow[t]{2}{*}{$\mathrm{Mg}^{2+}$} & \multirow[t]{2}{*}{$\begin{array}{c}\text { Clay } \\
(<2 \mu \mathrm{m})\end{array}$} & \multirow{2}{*}{$\begin{array}{c}\text { Silt } \\
(2-50 \mu \mathrm{m}) \\
\left(\mathrm{g} \mathrm{kg}^{-1}\right)\end{array}$} & \multirow[t]{2}{*}{$\begin{array}{c}\text { Sand } \\
(>50 \mu \mathrm{m})\end{array}$} \\
\hline & $(\%)$ & $\left(\mathrm{cmol} \mathrm{kg}^{-1}\right)$ & $\left(m^{2} g^{-1}\right)$ & $\left(\mathrm{dS} \mathrm{m} \mathrm{m}^{-1}\right)$ & \multicolumn{3}{|c|}{$\left(\mathrm{mg} \mathrm{kg}^{-1}\right)$} & & & & \\
\hline 5.7 & 3.8 & 27.6 & 224 & 0.89 & 6 & 14 & 233 & 128 & 440 & 525 & 35 \\
\hline
\end{tabular}

Table 1 b) Chemical characteristics of the High ionic strength water (HIS) and Low ionic strength water used in the biological assays

\begin{tabular}{|c|c|c|c|c|c|c|c|c|c|c|}
\hline \multirow{3}{*}{$\begin{array}{l}\text { Liquid } \\
\text { medium }\end{array}$} & \multirow{3}{*}{$\mathrm{pH}$} & \multicolumn{4}{|c|}{ Cations } & \multicolumn{4}{|c|}{ Anions } & \multirow{3}{*}{$\begin{array}{c}\text { Ionic }^{\dagger} \\
\text { Strength } \\
\text { M }\end{array}$} \\
\hline & & $\mathrm{Na}^{+}$ & $\mathrm{K}^{+}$ & $\mathrm{Ca}^{2+}$ & $\mathrm{Mg}^{2+}$ & $\mathrm{CaCO}_{3}$ & $\mathrm{HCO}_{3}{ }^{-}$ & $\mathrm{Cl}^{-}$ & $\mathrm{SO}_{4}^{2-}$ & \\
\hline & & \multicolumn{4}{|c|}{$\left(\mathrm{mg} \mathrm{l}^{-1}\right)$} & \multicolumn{4}{|c|}{$\left(\mathrm{mg} \mathrm{l}^{-1}\right)$} & \\
\hline HIS & 7.4 & 33.8 & 2.7 & 186 & 111.6 & 0 & 122 & 72.8 & traces & 0.024 \\
\hline LIS & 5.9 & - & - & - & - & - & - & - & - & 0.0021 \\
\hline
\end{tabular}

$\dagger$ (Ionic strength of liquid medium + ionic strength of soil solution)

\subsection{Assays of bacterial affinity and adsorption to different aggregate sizes}

\subsubsection{Bacterial adsorption}

The bacterial adsorption assay was based on the protocol proposed by Oliver and Clegg (2007), which consists of four stages:

1) Preparation of suspensions

Suspensions of $1 \mathrm{~g}$ soil and $10 \mathrm{ml}$ of high and low ionic strength water were prepared. The suspensions were shaken for $15 \mathrm{~h}$ with an end-to-end shaker at $500 \mathrm{rpm}$. The energy allowed obtaining an aggregate size distribution (ASD) similar to that found in situ after the effect of a representative rainfall over the basin under study. The ASD values obtained by this procedure were similar to those found by simulating rain with intermediate intensities $\left(60 \mathrm{~mm} \mathrm{~h}^{-1}\right)$ (Kraemer, 2011b).

2) Inoculation

LIS and HIS water-soil suspensions were inoculated with two strains of E. coli: a laboratory strain (ATCC 8739) and a wild strain. The wild strain was isolated from bovine feces collected where the soil and water samples were collected. The strain was isolated and identified by the use of differential selective media (CHROMOBRIT, Britania) and by morphological (shape, size, gram test and metallic green) (Kraemer et al., 2011c) and biochemistry tests (Brock and Madigan, 1993). These strains were grown on Trypticase soy broth, at $35{ }^{\circ} \mathrm{C}$ for $24 \mathrm{~h}$, resuspended, centrifuged, and washed twice with sterile saline solution $(0.85 \mathrm{NaCl})$. After shaking the soil suspensions, inoculation was carried out to achieve a final concentration of $1 \times 10^{7} \mathrm{CFU} \mathrm{ml}{ }^{-1}$. To achieve this concentration a curve of absorbance $(600 \mathrm{~nm}) /$ bacterial concentration was built. The inoculum concentration chosen has been previously used by many researchers to represent a maximum concentration of microorganisms in runoff on fecal matter (Guber et al., 2005, Oliver et al., 2007). After inoculation, the solution was taken back to the shaker for $2 \mathrm{~h}$ at $500 \mathrm{rpm}$ in order to achieve an optimal relationship between the microorganisms and the soil. It has been previously determined that $2 \mathrm{~h}$ are sufficient to achieve a balance between the microorganisms in suspension and those associated to the soil fractions (Ling et al., 2002, Gannon et al., 1991).

3) Sedimentation

The inoculated suspensions were transferred to a $100 \mathrm{ml}$ flask and diluted with $50 \mathrm{ml}$ of sterile HIS and LIS as corresponded. The dilution facilitates the separation of the different aggregate sizes during sedimentation (Oliver et al., 2007). Then, we proceeded to separate different size fractions by taking $0.1 \mathrm{ml}$ aliquots at $10 \mathrm{~mm}$ depth in the times established according to the law of Stokes for sizes of 50,20,3 and $2 \mu \mathrm{m}$.

4) CFU count

Aliquots of the different aggregate sizes obtained by sedimentation were seeded in triplicate in VBR Agar (Biokar Diagnostics) and incubated in an oven at $36^{\circ} \mathrm{C}\left( \pm 1^{\circ} \mathrm{C}\right)$ for $24 \mathrm{~h}$. Finally, we proceeded to count the $\mathrm{CFU} \mathrm{ml}{ }^{-1}$ in all treatments (APHA, 1996).

The experiment was conducted under sterile conditions at a constant temperature of $20^{\circ} \mathrm{C}$.

$\mathrm{CFU}$ values $\mathrm{ml}^{-1}$ of each aggregate size (bacterial distribution) were obtained by the difference between the CFU ml ${ }^{-1}$ of the fraction considered and the following fraction of a smaller size. This difference is attributed to the joint sedimentation of $E$. coli and the soil aggregates. Changes in the size of the populations of $E$. coli by regrowth and cell death in the suspensions during the sedimentation were considered insignificant due to the very short time of sedimentation (40 minutes).

The relative bacterial adsorption was calculated from the sum of the bacterial proportion of all the fractions in relation to the bacterial proportion found in the $<2 \mu \mathrm{m}$ fraction, in which it is considered that there are no adsorbed bacteria. It can not be stated that in this fraction the bacteria found are attached, since they may be either adsorbed or in the form of 
"free and independent cells." Thus, the bacterial adsorption obtained is relative and not real because the adsorption that may occur in particles $<2 \mu \mathrm{m}$ is not computed.

\subsubsection{Bacterial affinity}

The bacterial affinity to the different aggregate sizes was calculated as the ratio between the CFU ml ${ }^{-1}$ of each fraction and the respective specific surface area (SSA) (Table 2).

To simulate the ASD and be able to calculate the specific surface area, $20 \mathrm{~g}$ of soil were shaken (with an end-to-end shaker) for $15 \mathrm{~h}$ (in triplicate). Since the energy used in this procedure was similar to that used in the preparation of the soil suspensions to be inoculated, the two methodologies are comparable. This analysis was carried out by the method of Robinson's pipette with distilled water. The ASD was grouped in the same ranges of sizes used for the bacterial assay ( $>50 \mu \mathrm{m}, 20-50 \mu \mathrm{m}, 3-20 \mu \mathrm{m}, 2-3 \mu \mathrm{m}$ and $<2 \mu \mathrm{m}$ ). We considered a particle density of $2.65 \mathrm{~g} \mathrm{~cm}^{-3}$ and the volume of particles was calculated from the radius of the mid point of each size fraction except for $>50 \mu \mathrm{m}$, where $200 \mu \mathrm{m}$ was used as the upper limit to weigh particles in smaller fractions. Results are shown per milliliter to reflect the $1 \mathrm{ml}$ pipette sample (Oliver et al., 2007).

Table 2 Calculation of the specific surface area by aggregate size for the sample evaluated

\begin{tabular}{|c|c|c|c|c|c|c|c|}
\hline $\begin{array}{c}\text { Size of the } \\
\text { particle } \\
(\text { diameter }, \mu \mathrm{m})\end{array}$ & $\begin{array}{c}\text { Equivalent radius used } \\
\text { in the calculations } \\
(\mu \mathrm{m})\end{array}$ & $\begin{array}{c}\text { Total mass } \\
\left(\mathrm{g} \mathrm{ml}^{-1}\right)\end{array}$ & $\begin{array}{c}\text { \% of } \\
\text { soil }\end{array}$ & $\begin{array}{c}\text { Spheric volume } \\
\text { of the particle } \\
\left(\mathrm{cm}^{3}\right)\end{array}$ & $\begin{array}{c}\text { Number of } \\
\text { particles in } \\
1 \mathrm{ml}\end{array}$ & $\begin{array}{c}\text { Spheric surface } \\
\text { of the particle } \\
\left(\mathrm{mm}^{2}\right)\end{array}$ & $\begin{array}{c}\text { Surface by } \\
\text { particle size in } \\
1 \mathrm{ml}^{2}\left(\mathrm{~mm}^{2}\right)\end{array}$ \\
\hline$>50$ & 37.5 & 0.198 & 19.8 & $1.24 \times 10^{-7}$ & $4.14 \times 10^{3}$ & $1.77 \times 10^{-2}$ & $7.32 \times 10^{1}$ \\
\hline $20-50$ & 17.0 & 0.128 & 12.9 & $1.15 \times 10^{-8}$ & $2.89 \times 10^{4}$ & $3.63 \times 10^{-3}$ & $1.05 \times 10^{2}$ \\
\hline $3-20$ & 6.0 & 0.474 & 47.4 & $5.08 \times 10^{-10}$ & $2.42 \times 10^{6}$ & $4.52 \times 10^{-4}$ & $1.09 \times 10^{3}$ \\
\hline $2-3$ & 1.3 & 0.050 & 5.0 & $5.17 \times 10^{-12}$ & $2.51 \times 10^{7}$ & $2.12 \times 10^{-5}$ & $5.33 \times 10^{2}$ \\
\hline$<2$ & - & - & 15.0 & - & - & - & - \\
\hline
\end{tabular}

\subsection{Statistical analysis}

The effects of the treatments on bacterial distribution, absorption and affinity were evaluated using general linear models in the R program (lm function, R Development Core Team, 2011). These models included three factors: liquid medium (HIS vs. LIS), aggregate size ( $>50,20-50,3-20,2-3 \mu \mathrm{m}$, and only in the case of bacterial distribution, the $<2$ $\mu \mathrm{m}$ category), bacterial type (laboratory vs. wild) and their interactions. The significance was assessed by analysis of variance (ANOVA) followed by Tukey HSD test. Bacterial affinity was log 10 transformed to meet ANOVA assumptions.

\section{Results}

The aggregate size was the treatment with most impact on all the biological variables measured, with a significant interaction with the liquid medium for all variables (Table 3). The bacterial strain was not significantly associated with any of the variables analyzed, showing only some positive trends in the relative bacterial adsorption and the bacterial affinity for the wild strain.

Table 3 Analysis of deviance for the effects of aggregate size, liquid medium and type of bacteria on bacterial distribution, adsorption and affinity. The F statistic is presented for each term in the model

\begin{tabular}{|l|c|c|c|}
\hline \multicolumn{1}{|c|}{ Aggregate size } & $\begin{array}{c}\text { Bacterial distribution } \\
(\%)\end{array}$ & $\begin{array}{c}\text { Relative bacterial } \\
\text { absorption (\%) }\end{array}$ & $\begin{array}{c}\text { Bacterial affinity } \\
\left(\text { CFU mm }{ }^{-2}\right)\end{array}$ \\
\hline Liquid medium & $46.7^{* * *}$ & $6.9^{* *}$ & $38.6^{* * *}$ \\
\hline Bacterial strain & $<0.1$ & $<0.1$ & 1.1 \\
\hline Aggregate size $\times$ liquid medium & $<0.1$ & $<0.1$ & 2.1 \\
\hline Aggregate size $\times$ bacterial strain & $4.5^{* *}$ & $3.9^{*}$ & $3.6^{*}$ \\
\hline liquid medium $\times$ bacterial strain & 1.4 & 2.4 & 1.8 \\
\hline Aggregate size $\times$ liquid medium $x$ bacterial strain & $<0.1$ & $<0.1$ & 0.1 \\
\hline
\end{tabular}

$* * * \mathrm{P}<0.001, * * \mathrm{P}<0.01, * \mathrm{P}<0.05$

\subsection{Bacterial distribution}

The bacterial distribution showed differences according to the different aggregate sizes but there was no marked effect of the liquid medium used (Fig. 1) or of the different strains used. The $<2 \mu \mathrm{m}$ fraction showed a much greater proportion of bacteria than the other aggregate sizes, with an average of 48\% (both strains and liquid media). The 3-20 $\mu \mathrm{m}$ and $2-3 \mu \mathrm{m}$ fractions showed a low proportion of bacteria, with no significant differences between the two liquid media $(\mathrm{P}<0.05)$, with averages of $12.62 \%$ and $9.23 \%$ respectively.

The 20-50 $\mu \mathrm{m}$ fraction showed an average bacterial proportion of $19.36 \%$ for both liquid media. The only size $-538-$ 
fraction whose bacterial distribution differed significantly between the liquid media used was that greater than $50 \mu \mathrm{m}$, corresponding $3.8 \%$ for the treatment with LIS and $13.3 \%$ for that with HIS.
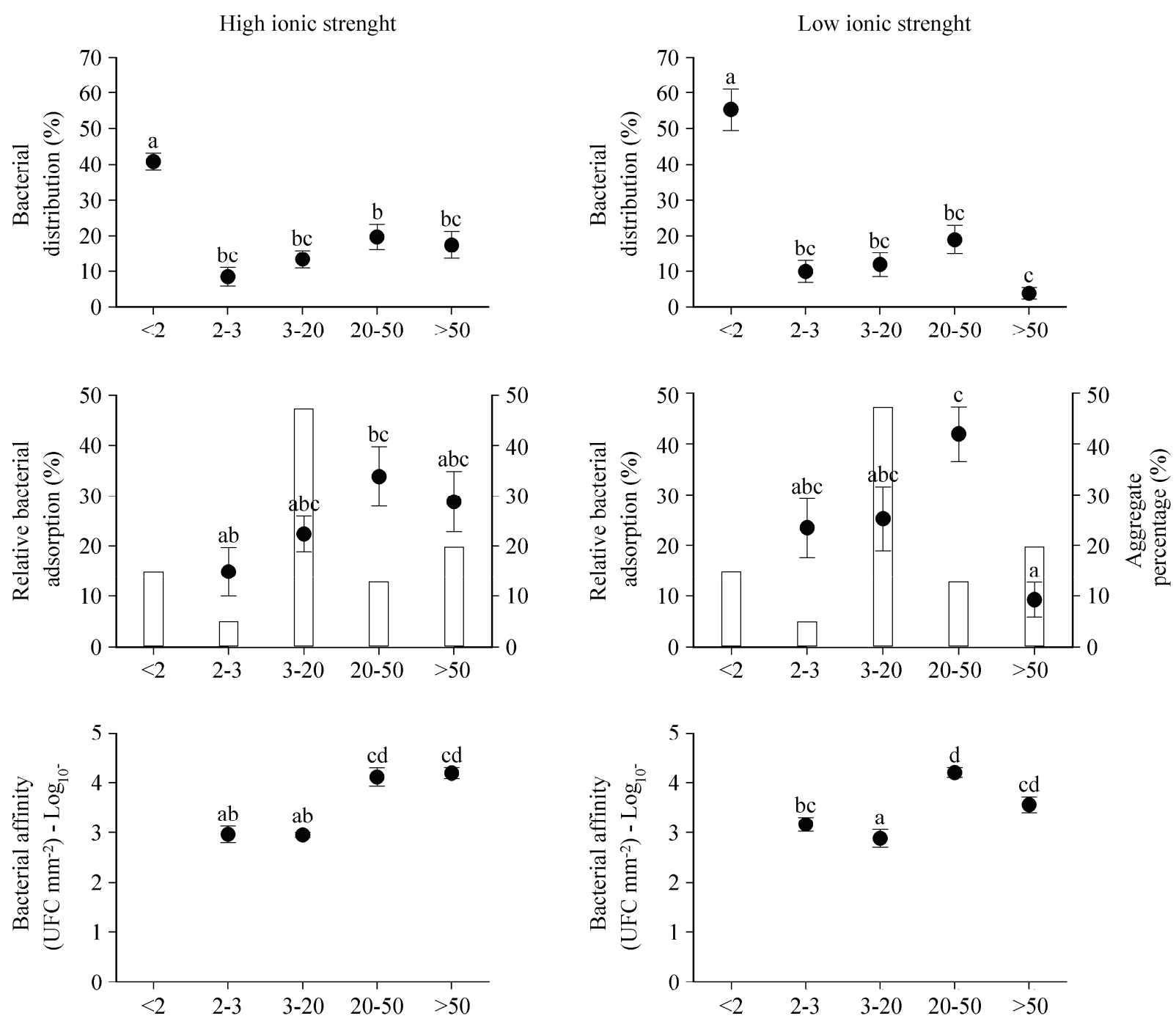

Aggregate size distribution $(\mu \mathrm{m})$

Fig. 1 Bacterial distribution, relative bacterial absorption and bacterial affinity for different aggregate sizes and liquid media (high and low ionic strength). The values correspond to the average of both bacterial strains. Horizontal lines represent \pm 1 standard error. Different letters indicate significant differences $\mathrm{P}<0.05$

\subsection{Bacterial adsorption}

Bacterial adsorption did not show the same trend as the aggregate size distribution (Fig. 1). While the higher percentage of aggregates was observed in the 3-20 $\mu \mathrm{m}$ fraction, for the fractions $>2 \mu \mathrm{m}$, the highest proportion of bacteria adsorbed was found in the $20-50 \mu \mathrm{m}$ fraction (coarse silt).

In the fractions with aggregate sizes $>2 \mu \mathrm{m}$ (where there are no free bacteria), the 20-50 $\mu \mathrm{m}$ fraction was the one which showed highest average bacterial adsorption (37.9\%) for both liquid media (Fig. 1). The remaining fractions showed average percentages for both liquid media of 19.2 and $23.9 \%$ for the $2-3$ and $3-20 \mu \mathrm{m}$ fractions respectively. The $>50 \mu \mathrm{m}$ fraction showed an average microbial adsorption of $19 \%$. This fraction showed an adsorption of $28.8 \%$ for the HIS treatment, whereas in the LIS $>50 \mu \mathrm{m}$ fraction presented the lowest adsorption for all the fractions and the two liquid media (9.24\%).

As a general trend, from the total absorption of each treatment (sum of the percentage of all fractions of bacteria associated with particles $>2 \mu \mathrm{m}$ ), we found relative bacterial adsorption values for the laboratory strain of $40.5 \%$ and $41.03 \%$ for the treatments LIS and HIS respectively, whereas for the wild strain the microbial adsorption was $49.3 \%$ for the LIS treatment and $56.6 \%$ for the HIS.

Although the effect of bacterial strains was not significant, these strains showed a trend of bacterial adsorption with an average difference in favor of the wild strain of $23 \%$, with differences in the liquid medium of 17.7 and $27.5 \%$ for the 
LIS treatment and HIS treatment, respectively. This means that the highest values of bacterial adsorption were found in the HIS treatment and wild strain and that the lowest values were found in the LIS treatment and laboratory strain.

\subsection{Bacterial affinity}

When normalizing the concentrations of microorganisms in the specific surface area of each aggregate size (bacterial affinity) (Table 2), significant differences of this variable in relation to aggregate size were observed (Table 3 ). At the same time, there was a significant interaction between aggregate size and the liquid medium but not with the strains used. As shown in Fig. 1, the highest values of bacterial affinity were found in the 20-50 $\mu \mathrm{m}$ fraction, in LIS and 20-50 and $>50 \mu \mathrm{m}$ in HIS. The 3-20 and 2-3 $\mu \mathrm{m}$ fractions showed the lower affinity values, regardless of the two ionic strength treatments.

\section{Discussion}

The results show that the aggregate size and the liquid medium used had a significant impact on the distribution of the bacterial proportion, adsorption and affinity to the solid medium. This highlights the importance of including both factors in the study of the transport of biological contaminants in liquid media.

\subsection{Bacterial association by aggregate size}

Considering all treatments, we obtained an average bacterial adsorption of $52 \%$, associated to aggregates $>2 \mu \mathrm{m}$. These values are high as compared with those found by other authors. Oliver et al. (2007) found 35\% of bacterial association in similar soils, whereas, using centrifugation techniques, Characklis et al. (2005) found an adsorption of $20-35 \%$ of $E$. coli associated to sedimentable particles. On the other hand, using significantly less diluted water/soil suspensions, Ling et al. (2002) found $99 \%$ adsorption in loamy soils.

In previous works, using the method of Ling et al. (2002) and the same soil sample as that used in this study, we found $63.8 \%$ of bacterial adsorption (Kraemer et al., 2010). Therefore, it is possible that the real adsorption was underestimated because bacteria associated to aggregates $<2 \mu \mathrm{m}$ not taken into account by the methodology used in this work.

With respect to this size fraction of clay and its influence on water pollution, we may hypothesize that there would be no differences in the hydrological behavior between free organisms and those absorbed to so small particles. However, the latter would present higher survival in the water than the former. For the above reasons, the impact of this solid fraction in the process of biological contamination of surface waters should not be underestimated.

In the $>2 \mu \mathrm{m}$ fractions, the size range that presented the highest bacterial proportion was coarse silt $(20-50 \mu \mathrm{m})$. This is not in agreement with that found by Oliver et al. (2007), who, using the same methodology, found the highest proportion in the 15-4 $\mu \mathrm{m}$ range (followed by that of 30-16 $\mu \mathrm{m}$ ) or with that observed by Auer and Niehaus (1993), who found an association of more than $90 \%$ between fecal coliform and particles in the range of 0.4 to $10 \mu \mathrm{m}$. Borst and Selvakumar (2003), on the other hand, found no relationship between coliforms and fecal streptococci and particle size.

Considering the size range of aggregates of $2-50 \mu \mathrm{m}$ (total silt), the soil had a relative adsorption of $79.5 \%$ and $11.2 \%$ for the sand fraction, whereas, as mentioned above, the calculation of the fraction associated to the clay size was not taken into account. In experiments carried out with $E$. coli in storm runoff, Jeng et al. (2005) found very similar values of approximately $80 \%, 18 \%$ and $2 \%$ associated to the aggregate size of silt, clay and sand respectively. In previous works carried out in the same soil under simulated field rain, we found that $98 \%$ of the microorganisms were associated to silt-sized aggregates and that only $2 \%$ were associated to sands (Kraemer et al., 2011b).

\subsection{Liquid medium and bacterial strain}

It has been shown that the use of HIS water induces higher adsorption than LIS. Many authors have recognized that an increase in electrolyte concentration results in an increase in bacterial association to solids. Huub et al. (1995), using eight bacterial strains in liquid media with ionic strengths between 0.0001 and $1 \mathrm{M}$, and Stevik et al. (1999), using distilled water and two solutions of 0.00725 and $0.097 \mathrm{M}$, concluded that bacterial adsorption increases as ionic strength increases.

Regarding the cation type present, we have previously found that calcium concentration was the water chemical parameter that best explained the adsorption of E. coli in liquid media (Kraemer et al., 2008). In the present study we found an important concentration of this divalent cation (Table 1b). In bacterial transport studies, Powelson and Mills (2001) found similar results, where the inclusion of a solution dominated by $\mathrm{Ca}^{+2}$ resulted in a lower transport of microorganisms in the water, indicating an increase in the adsorption to the solid fraction.

Both the ionic strength of the solution and the type of dominant cation influence the balance of electrostatic charges, which would explain the reversible adsorption of the microorganism to the solid. According to the DVLO theory (Derjaguin and Landau, 1941, Verwey and Overbeek, 1948), the ionic strength of the liquid will affect the thickness of the double layer and therefore the charge balance and the adsorption capacity of microorganisms to the particles.

The ionic strength of the liquid affects the charge balance in small aggregates, where there is a higher proportion of 
colloids. Nevertheless, the $>50 \mu \mathrm{m}$ fraction was the one which showed a greater impact in HIS treatment on the increase in bacterial proportion. Conversely, a higher proportion of bacteria was found in the $<2 \mu \mathrm{m}$ fraction in the LIS treatment than in the HIS treatment.

This difference could be a result of the higher ionic strength and the presence of $\mathrm{Ca}^{+2}$ in the HIS treatment, which increases the adsorption of aggregates $>2 \mu \mathrm{m}$, whereas the increase in bacterial proportion in the $<2 \mu \mathrm{m}$ fraction in the LIS treatment could be due to an increase in the proportion of microorganisms associated to soil aggregates.

In this sense, it is possible LIS causes a greater dispersion of the soil than HIS and because of that there would be a lower concentration of aggregates in the $>50 \mu \mathrm{m}$ fraction than that previously calculated, and thus fewer bacteria. To test this hypothesis, we analyzed the ions present in the HIS treatment and found a significant concentration of calcium but also of bicarbonates, which would precipitate this cation (Table 1b). Given that the sodium concentration and the SAR (Sodium Absorption Ratio) are not negligible, the maintenance of soil aggregation by the HIS water is also limited, since it behaves similarly to the LIS treatment.

Regarding the behavior between the two strains used, there were no significant effects of the strain used on any of the variables tested. However, the wild strain tended to present higher values of bacterial adsorption (an average increase of $23 \%$ in both treatments). Working on four silt and clay-loam soils and using the same wild strain, we also previously found a higher adsorption with the wild strain than with the laboratory bacteria, in all the cases with an average increase of $48 \%$, roughly equal to the percentage found in HIS treatment (Kraemer et al., 2011c).

More marked differences have been reported by Muirhead et al. (2006) in laboratory studies where the wild strain showed an adsorption of $81 \%$, while the laboratory strain showed an adsorption of only $24 \%$. A possible cause of this differential adsorption is the morphological differences between species and microbial strains, which could modify the balance and distribution of the electrostatic charges on the bacterial surface.

The laboratory and wild bacteria used in this experiment presented morphologies of coccus and coccobacillus respectively (Kraemer et al., 2011a). Similarly, other properties such as differences in extracellular substances, physiological state, hydrophobicity and motility could have influenced their behavior (Camper et al. 1993). The highest adsorption trends found in the wild strain imply a greater potential for contamination because it is very likely that the bacteria have a higher survival rate and thus greater opportunities to reach watercourses.

\subsection{Bacterial affinity}

The chemical, physical and structural differences of each fraction could be the cause of the different bacterial affinities in each aggregate size range. The high bacterial affinity found in the $20-50 \mu \mathrm{m}$ aggregate size is consistent with the results by Oliver et al. (2007), who, using the same methodology, found that its maximum value corresponded to the 16-30n $\mu \mathrm{m}$ fraction (almost completely included in the 20 to $50 \mu \mathrm{m}$ fraction). This affinity would explain the higher bacterial concentration found in this fraction, even when this was not the one with the largest relative proportion in weight. Palmateer et al. (1993), quoted by Oliver et al. (2007), who also normalized their data using the specific surface area, found a high colonization of fecal bacteria at a concentration of $6.5 \times 10^{5} \mathrm{CFU} \mathrm{mm} \mathrm{m}^{-2}$ in suspended sediments coming from agricultural drainage. This value is just above the overall average found in the present work: $1.78 \times 10^{4}$ CFU mm $\mathrm{mm}^{-2}$. The bacterial affinity for the coarse silt could be explained by the high percentage of low density porous mineral that exists in the region where samples were taken (Cosentino and Pecorari, 2002). These silt-sized minerals may have physical, chemical and structural properties that may favor microbial association. In addition, working with soils from the same region, Morrás et al. (1995) showed that silt-sized particles have electrostatic phenomena evidenced by the existence of ion exchange sites.

To advance in the understanding of the causes of the existence of different affinities, the chemical and physical analysis of each size fraction should be carried out separately in order to isolate the factors involved and to improve the understanding of the processes that control bacterial affinity.

\subsection{Implications for control of water pollution}

The particle size distribution of the soil analyzed, together with the high bacterial affinity found in the silt size fraction, especially in coarse silt, suggests a potential risk of these particles in the dynamics of bacterial transport. This corroborates the hypothesis by Chagas (2007), who stated that the sediments generated by sheet erosion in the Rolling Pampa may have a high ability to absorb and transport various chemical and/or biological agents such as pesticides, bacteria and viruses downhill.

Muirhead et al. (2006) estimated that bacteria need to be associated with soil particles $>63 \mu \mathrm{m}$ in diameter so as to sediment in the runoff and to particles $>500 \mu \mathrm{m}$ in order to be filtered by the pasture. The data presented here suggest a low effectiveness of filter strips. On the other hand, the study area has very low slopes $(0.5 \%)$ and very long slope lengths $(1000 \mathrm{~m})$, where there is a greater possibility of selective sedimentation and where vegetation can act as a filter.

Coyne et al. (1998) found that filter strips reduced $99 \%$ of the sediments, with a bacterial removal rate of 74 and $34 \%$ in different slopes, indicating that each situation should be analyzed specifically, separating the effect of the filtering strips in the infiltration/runoff relationship and the specific features of each situation, such as slope, soil type, and vegetation type used. On the other hand, it has been verified that there is significant bacterial association to particles International Journal of Sediment Research, Vol. 28, No. 4, 2013, pp. 535-543 
larger than $2 \mu \mathrm{m}$ that can not be controlled by filter strips, although they can indeed promote an increase in bacterial survival (Sherer et al., 1992; Jamieson et al., 2004).

Various computer programs such as SWAT (Soil and Water Assessment Tool) simulate bacterial transport according to the microbial adsorption (relative to the soil/water partition coefficient) and survival (by modifying the mortality rate). A critical mass of experiments aimed at studying bacterial adsorption to different soil sizes could allow an important adjustment in these models, improving the bacterial dynamics in the environment. The use of different water/soil relations and soil qualities is needed to corroborate the results presented.

\section{Conclusions}

The soil evaluated presented a different distribution, adsorption and affinity to $E$. coli for each aggregate size. The $<2$ $\mu \mathrm{m}$ aggregate size showed a higher proportion of bacteria than the rest of the aggregate sizes, with an average bacterial proportion of $48 \%$. In the $>2 \mu \mathrm{m}$ fractions (where there are no free bacteria), the $20-50 \mu \mathrm{m}$ fraction (coarse silt) was the one which presented highest average bacterial adsorption for both liquid media of $37.9 \%$. On the other hand, the highest values of bacterial affinity were found in the 20 to $50 \mu \mathrm{m}$ fraction (coarse silt) in the low ionic strength media and 20-50 and $>50 \mu \mathrm{m}$ in the high ionic strength media. However, the bacterial strains used revealed only some trends in the modification of these variables.

\section{Acknowledgement}

This work was supported by the project UBACY G045 and 0709. We thank Dr. Alfonso Buján and Dr. Eva Pawlac from the CNEA (Comisión Nacional de Energía Atómica) for their contribution in the sterilization of soil samples.

\section{References}

APHA. Standard methods of examination of water and wastewater. 20th edition. Washington DC. 998.

Auer M. and Niehaus S. 1993, Modelling fecal coliform bacteria I. Field and laboratory determination of loss kinetics. Water Research, Vol. 27, pp. 693-701.

Borst M. and Selvakumar A. 2003, Particle-associated microorganisms in stormwater runoff. Water Research, Vol. 37, pp. $215-223$.

Brock T. D. and Madigan M. T. 1993, Microbiología. Sexta edición. Prentice Hall Hispanoamericana S.A.

Burton G. A., Gunnison D. J. R., and Lanza G. R. 1987, Survival of pathogenic bacteria in various freshwater sediments. Applied Environmental Microbiology, Vol. 53, pp. 633-638.

Camper A. K., Hayes J. T., Sturman P. J., Jones W. L., and Cunningham A. B. 1993, Effects of motility and adsorption rate coefficient on transport of bacteria through saturated porous media. Applied Environmental Microbiology, Vol. 59, pp. $3455-3462$.

Chagas C. I. 2007, Calidad y contaminación del agua superficial como recurso para bebida animal en una cuenca representativa de Pampa Ondulada. Tesis Doctoral (Área Toxicología). Facultad de Ciencias Veterinarias, Universidad de Buenos Aires. Buenos Aires, 9 de agosto de 2007.

Characklis G. W., Dilts M. J., Simmons III O. D., Likirdopulos C. A., Krometis L. A. H., and Sobsey M. D. 2005, Microbial partitioning to settleable particles in stormwater. Water Research, Vol. 39, pp. 1773-1782.

Cosentino D. and Pecorari C. 2002, Limos de baja densidad: impacto sobre el comportamiento físico de los suelos de la región pampeana. Ciencia del Suelo, Vol. 20, No. 1, pp. 9-16.

Coyne M. S., Gilfillen R. A., Villalba A., Zhang Z., Rhodes R., Dunn L., and Blevins R. L. 1998, Fecal bacteria trapping by grass filter strips during simulated rain. Journal of Soil and Water Conservation, Vol. 53, pp. 140-145.

Derjaguin B. and Landau L. D. 1941, Theory of the stability of strongly charged lyophobic sols and of the adhesion of strongly charged particles in solutions of electrolytes. Acta Physicochima U.R.S.S., Vol. 14, pp. 633-662.

Edwards D. R., Coyne M. S., Vendrell P. F., Daniel T. C., Moore P. A. Jr., and Murdoch J. F. 1997, Fecal coliform and streptococcus concentrations in runoff from grazed pastures in northwest Arkansas. Journal of the American Water Resources Association, Vol. 33, pp. 413-422.

Fontes D. E., Mills E. L., Hornberger G. M., and Herman J. S. 1991, Physical and chemical factors influencing transport of microorganisms through porous media. Applied and Environmental Microbiology, Vol. 57, No. 9, pp. 2473-2481.

Gannon J., Mingelgrin U., Alexander M., and Wagenet R. J. 1991, Bacterial transport through nonhomogenous soil. Soil Biology and Biochemistry, Vol. 23, pp. 1155-1160.

Guan T. Y. and Holley R. A. 2003, Pathogen survival in swine manure environments and transmission of human enteric illness. A review. Journal of Environmental Quality, Vol. 32, pp. 383-392.

Guber A. K., Shelton D. R., and Pachepsky Y. A. 2005, Effect of manure on Escherichia coli attachment to soil. Journal of Environmental Quality, Vol. 34, pp. 2086-2090.

Huub H. M. R., Norde W., Lyklema J., and Zehnder A. J. B. 1995, The isoelectric point of bacteria as an indicator for the presence of cell surface polymers that inhibit adhesion. Colloids and Surfaces B: Biointerfaces, Vol. 4, No. 4, pp. 191-197.

INTA. 1973, Carta de Suelos. Hoja 3360-33. Pérez Millán. E=1:50.000. p. 45.

Jamieson R., Gordon R., Joy D., and Lee H. 2004, Assessing microbial pollution of rural surface waters: a review of current watershed scale modeling approaches. Agricultural Water Management, Vol. 70, pp. 1-17.

Jeng H. W. C., England A. J., and Bradford H. B. 2005, Indicator organisms associated with stromwater suspended particles and estuarine sediment. Journal Environmental Science and Health A Tox. Hazard. Subs. Environ. Eng., Vol. 40, No. 4, pp. $779-791$. 
Kay D., Edwards A. C., Ferrier R. C., Francis C., Kay C., and Rushby L. et al. 2007, Catchment microbial dynamics: The emergence of a research agenda. Progress in Physical Geography, Vol. 31, pp. 59-76.

Klute A. 1986, Water retention: Laboratory methods. In: Klute, A. (ed.). Methods of soil análisis. 2nd.ed. ASA and ASSA. Madison, WI, USA. Vol. 1, pp. 1188.

Kraemer F. B., Chagas C. I., Moretton J., and Paz M. 2008, Capacidad de resuspensión de patógenos en sedimentos de la cuenca del Tala. Efecto del medio líquido. Actas del Congreso Argentino de la Ciencia del Suelo. Potrero de los Funes (SL), Argentina. Pag. 492.

Kraemer F. B., Chagas C. I., Morrás H., Moretton J., Paz M., and Garibaldi L. A. 2010, Influence of physical and chemical soil properties on the adsorption of E. coli in Mollisols and Alfisols of Argentina. New advances in research and management of word mollisols. Proceedings of International Symposium on soil quality and management of world mollisols. 13 al 16 de Julio de 2010. Harbin, China.

Kraemer F. B. 2011a, Transporte de microorganismos indicadores de contaminación fecal en una cuenca de Pampa Ondulada. El rol de las propiedades físicas y químicas de los suelos y los sedimentos. Tesis de Magister Scientiae. Escuela para Graduados de la Facultad de Agronomía, Universidad de Buenos Aires. Aprobada el 30 de Agosto 2011.

Kraemer F. B., Chagas C. I., Irurtia C., and Garibaldi L. A. 2011b, Bacterial retention in three soils of the Rolling Pampa, Argentina, under simulated rainfall. Journal of Soil Science and Environmental Management, Vol. 2, No. 11, pp. 341-353.

Kraemer F. B, Chagas C. I, Cosentino D. J, Paz M., and Moreton J. A. 2011c, La textura del suelo como factor regulador de la adsorción de Escherichia coli en una cuenca de la Pampa ondulada. Revista Argentina de Microbiología, Vol. 43, pp. 87-93.

Ling T. Y., Achberger E. C., Drapcho C. M., and Bengtson R. L. 2002, Quantifying adsorption of an indicador bacteria in a soil-water system. Transactions of the ASAE, Vol. 45, pp. 669-674.

Lombardi B., Dapino M. A., Montardit P. R., and Torres Sánchez R. M. 2001, Aproximación al valor de superficie especifica por un método manual y simple. Jornadas SAM - CONAMET - AAS 2001, Septiembre de 2001, pp. 251-256.

Marshall K. C. 1975, Clay mineralogy in relation to survival of soil bacteria. Annual Review of Phytopathology, Vol. 13, pp. $357-373$.

Morrás H. J. M. 1995, Mineralogy and cation exchange capacity of the fine silt fraction in two soils from the Chaco region (Argentina). Geoderma, Vol. 64, pp. 281-295.

Muirhead R. W., Collins R. P., and Bremer P. J. 2005, Erosion and subsequent transport state of Escherichia coli from cowpats. Applied Environmental Microbiology, Vol. 71, pp. 2875-2879.

Muirhead R.W., Collins R. P., and Bremer P. J. 2006, Interaction of Escherichia coli and soil particles in runoff. Applied Environmental Microbiology, Vol. 72, pp. 3406-3411.

Oliver D. M., Clegg C. D., Haygarth P. M., and Heathwaite A. M. 2005, Assessing the potential for pathogen transfer from grassland soils to surface waters. Advances in Agronomy, Vol. 85, pp. 125-180.

Oliver D. M., Clegg C. D., Heathwaite A. L., and Haygarth P. M. 2007, Preferential attachment of Escherichia coli to different particle size fractions of an agricultural grassland soil. Water, Air \& Soil Pollution, Vol. 185, No. 1, pp. 369-375.

Palmateer G., McLean D., Kutas W., and Meissner S. 1993, Suspended particulate/bacterial interaction in agricultural drains. In: Rao, S.S. (Ed.), Particulate Matter and Aquatic Contaminants, Lewis Publishers, Boca Raton, Fl.

Powelson D. K. and A. L. Mills. 2001, Transport of Escherichia coli in sand columns with constant and changing water contents. Journal of Environmental Quality, Vol. 30, pp. 238-245.

R Development Core Team 2011, R: A language and environment for statistical computing. R Foundation for Statistical Computing, Vienna, Austria. ISBN 3-900051-07-0, URL http://www.R-project.org/.

Schillinger J. E. and Gannon J. J. 1985., Bacterial adsorption and suspended particles in urban stormwater. Journal of the Water Pollution Control Federation, Vol. 57, pp. 384-389.

Sherer B. M., Miner J. R., Moore J. A., and Buckhouse J. C. 1992, Indicator bacterial survival in stream sediments. Journal of Environmental Quality, Vol. 21, pp. 591-595.

Signor R. S., Roser D. J., Ashbolt N. J., and Ball J. E. 2005, Quantifying the impact of run-off events on the microbiological contaminant concentrations entering drinking surface source waters. Journal of Water and Health, Vol. 3, pp. 453-468.

Soil Conservation Service. 1972, Soil survey laboratory methods and procedures for collecting soils samples. Soil Surv. Report, 1. USDA, Washington (USA).

Stenstrom T. A. 1989, Bacterial hydrophobicity: An overall parameter for the measurement of adhesion potential to soil particles Applied Environmental Microbiology, Vol. 55, No. 1, pp. 142-147.

Stevik T. K., Geir A., Hanssen J. F., and Jenssen P. D. 1999, The Influence Of Physical And Chemical Factors On The Transport Of E. Coli Through Biological Filters For Wastewater Purification. Water Research, Vol. 33, No. 18, pp. 3701-3706.

Stotzky G. 1985, Mechanisms of adhesion to clays, with referente to soil systems. In BacterialAdhesion: Mechanisms and Physiological Significance. Savage DC and Fletcher MH, eds. New York, N.Y.: Plenum Publishing, pp. 195-253.

Sutherland I. W. 1983, Microbial exopolysaccharides-their role in microbial adhesion in aqueous systems. Critical Reviews in Microbiology, Vol. 10, pp. 173-201.

Tyrrel S. F. and Quinton J. N. 2003, Overland flow transport of pathogens from agricultural land receiving faecal wastes. Journal of Applied Microbiology, Vol. 94, No. s1, pp. 87-93.

Verwey E. J. W. and Overbeek J. Th. G. 1948, Theory of the stability of lyophobic colloids, Elsevier, Amsterdam (1948).

Walkley A. and Black I. A. 1934, An examination of the Degjareff method for determining soil organic matter and a proponed modification of the cromi acid titration method. Journal of American Society of Agronomy, Vol. 24, pp. 256-275. 